\title{
PENGARUH BUDAYA KERJA, INTEGRITAS DAN KEPERCAYAAN TERHADAP ORGANIZATIONAL CITIZENSHIP BEHAVIOR PADA DOSEN UNIVERSITAS NEGERI JAKARTA
}

\author{
Endang Sri Rahayu \\ Fakultas Ekonomi, Universitas Negeri Jakarta \\ endang_sri_rahayu@yahoo.com
}

\begin{abstract}
The objective research is to obtain information concerning to the effect of job culture, integrity, and trust towardteachers organizational citizenship behavior. The research was conducted by using survey method with path analysis in testing hypothesis. In this research, 115 from 950 teacher of teachers selected random sampling. The research was focused on four aspect; job culture, integrity, and trust towardteachers organizational citizenship behavior. The data were colected with questionnaire and analyzed with path analysis. Result on the analyisis it is conculaded that (1) there the positive direct effect of job culturetowards organizational citizenship behavior, (2) there is positive direct effect of integrity towards organizational citizenship behavior, (3) there is positive direct effect of trust towards organizational citizenship behavior, (4) there is positive direct effect of job culture towards trust, (5) there is positive direct effect of integrity towards trust, and there is positive direct effect of job towards culture integrity
\end{abstract}

Keywords: organizational citizenship behavior, organizational job culture, integrity, and trust 


\section{PENDAHULUAN}

Sumber daya manusia dalam suatu organisasi merupakan hal yang penting dan berpengaruh bagi kemajuan setiap organisasi, karena itu peningkatan kualitas sumber daya manusia merupakan sesuatu yang harus dilakukan sebagai usaha untuk meningkatkan kinerja dalam sebuah organisasi agar dapat bertahan dan bersaing dalam persaingan global. Menghadapi tantangan globalisasi, pemerintah telah mencanangkan paradigma baru pendidikan tinggi sebagaimana yang terisyarat pada Kerangka Pengembangan Pendidikan Tinggi Jangka Panjang 19962005. Paradigma baru ini menitiksentralkan kualitas perguruan tinggi (PT). Penerapannya terus dimantapkan oleh pemerintah, dalam hal ini Depdiknas, melalui aktualisasi asas otonomi perguruan tinggi (Depdiknas), dari semua tantangan tersebut peran sumber daya manusia terutama para dosen sangat penting.

Dosen adalah SDM yang memiliki peran yang sangat sentral dalam semua aktivitas di perguruan tinggi dan mempunyai andil dalam rangka building mahasiswa untuk berhadapan dengan realitas kehidupan yang penuh dengan persaingan. Oleh karena itu dosen berperan penting sebagai salah satu mata rantai membangun kualitas sumber daya manusia. Agar dapat berperan secara maksimal sesuai dengan fungsinya maka dosen memiliki beberapa kriteria antara lain: pertama adalah produktif secara intelektual berarti seorang dosen adalah orang yang mampu mengimplementasikan Tri Dharma Perguruan Tinggi (pendidikan dan pengajaran, penelitian dan pengembangan dan pengabdian kepada masyarakat) dengan baik, kedua korelatif dengan kemampuan dan latar belakang pengetahuan yang dimiliki, berarti seorang dosen di samping memiliki tingkat pendidikan yang sesuai dengan jenjang keilmuan yang diajarkannya, juga perlu ditopang oleh pengalaman mengajar yang progresif sehingga terjadi proses kematangan mengatasi dinamika psikologi pendidikan yang banyak menuntut upaya toleransi pemikiran dan strategi pola pembelajaran kepada mahasiswa, ketiga adalah memiliki sikap yang baik dan menjadi tauladan bagi para mahasiswanya dalam berperilaku, setiap tindak-tanduk seorang dosen biasanya menjadi cermin bagaimana sikap mahasiswa terhadap dosennya, keempat dan yang paling penting bagi seorang dosen adalah mampu berkomunikasi dan berperan sebagai pendidik sekaligus pengajar bagi peserta didiknya.

Direktorat Jenderal Pendidikan Tinggi (Dikti), 2011 menyatakan bahwa jumlah dosen di Indonesia sudah melebihi 180.000 orang dan diperkirakan hanya 1,1 persen yang mampu meneliti dengan layak. Sehingga kontribusi Indonesia pada perkembangan ilmu pengetahuan 
sangat rendah, hal ini dapat dilihat bahwa Indonesia berada pada peringkat ke-65 dengan Jumlah artikel ilmiah yang dihasilkan Indonesia hanya sebanyak 12.871 artikel, Sebagai perbandingan, di lingkungan ASEAN Indonesia berada pada posisi di bawah Thailand dan Malaysia yang menduduki posisi ke 42 dan 43, Jika dibandingkan dengan jumlah dosen di Indonesia, jumlah karya ilmiah tersebut memang masih mengkhawatirkan. Jika dihitung per kepala dosen, maka jumlah dokumen per kapitanya hanya sebesar 0.07. Artinya, tujuh paper dihasilkan oleh 100 orang dosen di Indonesia. Indikator ini menyisakan perkerjaan rumah bagi para pendidik, terutama dosen yang mengemban Tri Dharma Perguruan Tinggi, salah satunya adalah penelitian, dan salah satu tahap penting dalam penelitian adalah publikasi.

Perilaku yang menjadi tuntutan organisasi saat ini tidak hanya perilaku " in role "tetapi juga " extra role", perilaku ini disebut Organizational Citizenship Organizational (OCB) atau perilaku kewargaan organisasi. Organisasi yang sukses membutuhkan pegawai yang akan melakukan melebihi tugas pekerjaan yang biasa mereka lakukan atau pegawai yang akan memberikan kinerja melebihi harapan organisasi. Universitas Negeri Jakarta (UNJ) dalam mencapai tujuan sesuai dengan visi dan misinya membutuhkan pegawai dan dosen yang akan melakukan OCB. Wujud perilaku tersebut antara lain: membantu rekan dalam timnya, secara sukarela melakukan pekerjaan ekstra, menghindari konflik yang tidak perlu, menghargai semangat serta aturan dan peraturan organisasi/perusahaan, dan sesekali menolerir pekerjaan yang dapat menjadi beban, gangguan dan menyusahkan. Organisasi menginginkan dan membutuhkan pegawai yang akan melakukan hal-hal yang tidak ada dalam diskripsi tugas pekerjaannya. Bukti menunjukkan bahwa organisasi yang memiliki pegawai yang melakukan OCB memiliki kinerja yang lebih baik daripada organisasi yang pegawainya tidak melakukan OCB. Maka dari itu, bidang perilaku organisasi menganggap OCB sebagai suatu variabel terikat .

\begin{tabular}{lll}
\multicolumn{2}{c}{ Kemajuan organisasi yang } \\
paling utama dipengaruhi & oleh \\
sumberdaya & manusia. & Bagi
\end{tabular}
perguruan tinggi (PT), sumberdaya manusia yang menggerkkan PT yakni dosen. Semakin baik OCB dosen maka semakin baik pula PT tersebut. Tidak hanya itu, semakin tinggi OCB dosen juga meningkatkan nilai positif bagi PT tersebut. Tinggi rendahnya OCB dipengaruhi banyak faktor antara lain: (1) integritas (2) budaya kerja (3) kepercayaan (4) komitmen. Banyak faktor yang mempengaruhi kemauan seseorang untuk mau melakukan hal-hal positif diluar tugas utamanya, pada umumnya dipengaruhi oleh hal-hal yang berada di dalam maupun di luar diri individu dan berpengaruh langsung 
pada perilakunya. Selanjutnya dikatakan Organ, (1988) dalam Bolino, Turnley dan Bloodgood Organizational Citizenship Behavior (OCB), adalah perilaku karyawan yang melebihi peran yang diwajibkan, yang tidak secara langsung atau eksplisit diakui oleh sistem reward formal.

Perilaku kewargaan organisasi (OCB) yang rendah akan berdampak langsung pada berkurangnya efektivitas dan efisiensi dari sebuah organisasi. Dosen/Karyawan dengan perilaku kewargaan organisasi (OCB) yang rendah ditandai dengan perilaku pasif karyawan dalam melakukan pekerjaan. Dosen akan bekerja sesuai dengan tuntutan tugas yang diemban saja. Namun,tidak menumbuhkan kesediaan dalam melakukan tugas diluar tuntutan tugas tersebut. Pada kenyataannya kesediaan dosen dalam pekerjaan diluar tuntutan tugas dosen akan mendorong usaha organisasi tersebut menuju pada kesuksesan.

Budaya kerja, pada setiap organisasi berusaha mengembangkan suatu perilaku organisasi yang mencerminkan kejujuran dan etika yang dikomunikasikan secara tertulis dan dapat dijadikan pegangan oleh seluruh karyawan/ dosen. Budaya kerja harus memiliki akar dan memiliki nilai-nilai luhur yang menjadi dasar bagi etika pengelolaan suatu organisasi atau suatu entitas, nilai-nila iluhur dari seluruh lapisan karyawan/dosen yang dapat dijadikan pedoman dalam segala kegiatan yang dilakukan meliputi kegiatan para Dosen/karyawan UNJ.

Integritas adalah konsistensi antara nilai dan tindakan. Orang yang berintegritas akan bertindak konsisten sejalan dengan nilai-nilai, kode etik, serta kebijakan organisasi dan/atau profesi, walaupun dalam keadaan yang sulit untuk melakukannya. Integritas didefinisikan pula sebagai suatu kepribadian yang dilandasi oleh unsur jujur, berani, bijaksana, dan bertanggung jawab untuk membangun kepercayaan guna memberikan dasar bagi pengambilan keputusan yang andal. Bila dikaitkan dengan kode etik, integritas didefinisikan sebagai tindakan yang konsisten, sesuai dengan kebijakan dan kode etik organisasi. Secara konseptual, integritas dan nilai etika sangat jelas memberikan pengaruh posisif pada organisasi dan individu.

Demikian juga Kepercayaan (trust) berarti keyakinan terhadap kemampuan, atau karakter seseorang. Kepercayaan dapat membuat seseorang menjadi percaya diri, terbuka, jujur, bersedia mengambil risiko, dan merasa lebih nyaman dalam menjalin hubungan dengan orang lain. Kepercayaan juga dapat mengurangi resistensi terhadap perubahan, sebaliknya ketidakpercayaan (distrust) akan menyebabkan seseorang menjadi bersifat tertutup, tidak percaya diri, enggan mengambil risiko, dan tidak nyaman dalam menjalin hubungan dengan orang lain. Akibat tidak adanya kepercayaan, produktivitas melemah, peluang-peluang pengembangan 
dan perbaikan terlewatkan, dan kinerja merosot. Dalam sebuah organisasi, manfaat kepercayaan diantaranya adalah terciptanya iklim saling berbagi informasi dan kolaborasi. Ketika seorang karyawan yakin bahwa ide-ide dan informasi yang disampaikannya akan dihargai, inisiatif dan kreativitasnya akan tumbuh.

OCB sangat penting bagi suatu organisasi, terutama untuk mendorong dan mengangkat organisasi tempat bekerja sebagai tempat untuk mengembangkan karir dan menghasilkan output yang baik. Realitas dilapangan dosen sebagai ujung tombak universitas dan sebagian memiliki OCB yang relatif tinggi, sehingga kinerjanya bagus dan berimplikasi pada peningkatan mutu lulusan lembaga pendidikan tersebut.

Latar belakang masalah dalam penelitian ini adalah 1) Apakah Budaya Kerja berpengaruh langsung terhadap Organizational Citizenship Behavior (OCB)? 2) Apakah integritas berpengaruh langsung terhadap Organizational Citizenship Behavior (OCB)? 3) Apakah Kepercayaan berpengaruh langsung terhadap Organizational Citizenship Behavior (OCB)? 4) Apakah Budaya kerja berpengaruh langsung terhadap Kepercayaan? 5) Apakah Integritas berpengaruh langsung terhadap Kepercayaan? 6) Apakah Budaya kerja berpengaruh langsung terhadap Integritas ?

\section{KAJIAN PUSTAKA}

\section{Organizational Behavior (OCB) \\ Citizenship}

Kinerja dari karyawan/dosen dinilai berdasarkan pada job description yang telah disusun oleh organisasi tersebut, melaksanakan tugas sebagaimana yang tercantum dalam job description ini disebut sebagai inrolebehavior (Graham and Dienesch, 1994). Sudah seharusnya untuk menilai kinerja karyawan/ dosen tidak hanya sebatas tugastugas yang terdapat dalam deskripsi kerjanya saja, bagaimanapun diperlukan peran ekstra demi terselesainya tugas-tugas tersebut.

Perilaku yang diperlihatkan oleh seorang karyawan/dosen atas kemauan sendiri diluar perilaku inrole, ini disebut prilaku extra-role, yang tidak dapat diatur oleh perusahaan. Perilaku extra-role ini biasa disebut sebagai organizational citizenship behavior (OCB). Dengan kata lain OCB merupakan perilaku pekerja yang melebihi tugas formalnya dan memberikan kontribusi positif pada keefektifan organisasi. OCB dapat termasuk "pembicaraan kesuksesan" lembaga/ perusahaan kepada pihak luar. Sedangkan menurut pendapat Schanke yang dikutip oleh Paul E. Spector, "OCB is behavior that goes beyond the formal requirement of a job. It consists of those voluntary things employees do to help their workers and employers" (Spector, 1997).

OCB merupakan perilaku yang melebihi persyaratan kerja formal. Ini terdiri dari hal-hal sukarela yang dilakukan 
karyawanuntuk membantu rekan kerja mereka dan perusahaan. Pendapat Organ dalam Jewell mengatakan bahwa OCB adalah: Helpfull, constructive gestures exhibited by organization members and valued or appresiated by officials, but not related directlyto individual productivity nor inhering in the enforceable requirements of the individual role.(Jewell,1998). Pengertian ini pada dasarnya menunjukan bahwa OCB merupakan perilaku menolong dan membangun yang ditunjukkan oleh anggota organisasi dan dinilai atau dihargai oleh manajemen organisasi tetapi tidak berhubungan langsung dengan produktivitas individu dan perilaku yang diperankan bukan merupakan tuntutan dari peran individu. Hal ini menegaskan makna bahwa OCB merefleksikan perilaku di luar peran dan tanggung jawab anggota organisasi yang sewajarnya. Pengertian perilaku kewargaan organisasi yang dijabarkan oleh para pakar sangat beragam, namun, pada dasarnya perilaku kewargaan organisasi merupakan perilaku dimana karyawan bersedia melakukan tugas diluar tuntutan tugas formal.

$\begin{gathered}\text { Pendapat senada dari } \\ \text { dan }\end{gathered}$ Baron,
Greenberg organizational citizenship behavior
is actions by organization members
that exceed theformal requirement
of their job" yang dapat diartikan
organizational citizenship behavior
(OCB) adalah tindakan anggota
organisasi yang melebihi
persyaratan kerja formal mereka

(A.Baron, 2000).

Selanjutnya Richard L. Daft juga mengatakan hal yang sama "organizational citizenship behavior yaitu perilaku kerja yang melebihi persyaratan kerja dan turut berperan dalam kesuksesan organisasi" (L. Daft, 2002). Hal yang sama juga dikemukakan oleh Robbins dan Timothy yang mendefinisikan OCB sebagai, "perilaku pilihan yang tidak menjadi bagian dari kewajiban kerja formal seorang karyawan, namun mendukung berfungsinya organisasi tersebut secara efektif" (Judge, 2008).

Perilaku seperti ini dibutuhkan untuk mendukung kegiatan-kegiatan dalam organisasi yang tidak selamanya dapat dilakukan secara formal melalui kegiatan-kegiatan rutin organisasi. Adakalanya dalam kondisi tertentu organisasi membutuhkan perilaku ekstra peran, terutama ketika organisasi memerlukan dukungan aktivitas dari para dosen yang tidak dapat diukur dengan uang. Selanjutnya Robert Kreitner dan Angelo Kinicki menyatakan, "Organizational citizenship behavior (OCB) consist of employee behavior thatare beyond thecall of duty" (Kreitner dan Kinicki, 2007), yang dapat diartikan bahwa, perilaku kewargaan organisasi terdiri dari perilaku karyawan yang berada diluar panggilan tugas. Pendapat senada dikemukakan Organ dalam Foote dan Tang yang mengartikan OCB sebagai: individual behaviour that is discretionary, not directly or

Available at.

http://journal.unj.ac.id/unj/index.php/econosains/article/view/939 
explicity recognizized by the formal reward system, and in the aggregate promotes the effective functioning of the organization (Foote and Tang). Hal ini berarti bahwa OCB adalah perilaku yang berdasarkan kesukarelaan yang tidak dipaksakan pada batas-batas pekerjaan dan tidak secara resmi menerima penghargaan tetapi mampu memberikan kontribusi bagi perkembangan produktivitas dan keefektifan organisasi.

Karyawan/dosen yang memiliki OCB yang tinggi, akan dapat mengendalikan perilakunya sendiri atau mampu memilih perilaku terbaik untuk kepentingan organisasinya, dengan kata lain adanya perilaku kewargaan ini ini maka interaksi sosial pada anggotaanggota organisasi menjadi lancar, mengurangi terjadinya perselisihan, dan meningkatkan efisiensi dalam mencapai tujuan organisasi. Perilaku ini muncul karena perasaan sebagai anggota organisasi dan ada kepuasan apabila dapat melakukan sesuatu yang lebih kepada organisasi. Perasaan sebagai anggota dan ada kepuasan bila melakukan suatu yang lebih hanya terjadi jika memiliki pemikiran yang positif terhadap organisasinya yang selama ini dirasakan dalam melakukan pekerjaan, hal ini bisa diperoleh melalui kultur kerja yang ada ataupun lainnya.

Jadi dapat dikemukakan bahwa OCB menggambarkan kemauan karyawan untuk menerima, mematuhi peraturan, prosedur organisasi, dan kemauan karyawan untuk menempatkan kepentingan pribadi mereka untuk keuntungan dan kelangsungan organisasi serta yang menggambarkan kemauan karyawan untuk secara aktif mengembangkan seluruh aspek kehidupan organisasi. Menurut Organ, Podsakoff \& MacKenzie (Organ. DW.Podsakof, 2000), mengintegrasi-kan berbagai konstruk OCB menjadi tujuh dimensi sebagai berikut:

1) Helping behavior/altruism/ courtesy/Perilaku menolong.

2) Sportsmanship, menunjukkan suatu kerelaan/toleransi tanpa mengeluh kendati keadaan di tempat kerja kurang menyenangkan.

3) Organizational compliance/ general compliance/ Organizational obedience, menunjukan sikap individu yang mematuhi segala peraturan, prosedur, dan regulasi organisasi .

4) Organizational loyalty/spreading goodwill.

5) Civic virtue/Organizational participation.

6) Individual Initiative conscientinousness. Meningkatkan kompetennya dan secara sukarela mengambil tanggung jawab, Organ (1983) menamakan dimensi ini sebagai conscientiousness

7) Self-development.

\section{Budaya Kerja}

Dalam membahas mengenai kultur/budaya kerja akan diawali dengan membicarakan pengertian 
budaya. Kata budaya (culture) mempunyai pengertian dan makna yang banyak, apabila kata ini dihubungkan dengan kata organisasi, dalam khasanah kata atau istilah di dalam studi administrasi manajemen sering ditemukan sejumlah istilah yang mirip dengan pengertian budaya. Kajian budaya pada organisasi bermula dari anggapan bahwa organisasi tidak statis, terus berkembang, dituntut untuk memiliki daya adaptasi, dan pemahaman analisa terhadap lingkungan eksternal serta internal.

Sistem pemaknaan bersama merupakan seperangkat karakter kunci dari nilai-nilai organisasi ("a system of shared meaning held by members that distinguishes the organization from other organization. This system of shared meaning is, on closer examination, a set of key characteristics that the organization values"). Robbins memberikan karakteristik budaya organisasi sebagai berikut: (1) Inovasi dan keberanian mengambil risiko (Inovation and risk taking), adalah sejauh mana organisasi mendorong para karyawan bersikap inovatif dan berani mengambil resiko. Selain itu bagaimana organisasi menghargai tindakan pengambilan risiko oleh karyawan dan membangkitkan ide karyawan; (2) Perhatian terhadap detil (Attention to detail), adalah sejauh mana organisasi mengharapkan karyawan memperlihatkan kecermatan, analisis dan perhatian kepada rincian. Ketika diterapkan pada organisasi ,konsep kultur di kaitkan dengan cara kerja dan aktivitas yang di miliki anggota-anggota suatu organisasi yang membedakan dengan organisasi lain, dengan tetap mengacu pada karakteristik utama budaya organisasi.

Menurut Pettigrew kultur adalah suatu sistem makna yang secara kolektif dan terbuka (publicy) disepakati untuk berlaku pada suatu kelompok pada waktu tertentu. Sistem ini terdiri dari istilah-istilah, bentuk-bentuk, kategori-kategori, dan citra-citra yang memberikan penafsiran terhadap situasi yang dihadapi seseorang (Pettigrew, 1979).

Dari pandangan Tylor di atas Redflied dalam Komaruddin punya pandangan lain yang menyatakan bahwa "budaya itu kumpulan dari "pemahaman bersama" dan perilaku yang mapan dari suatu masyarakat." (Pettigrew, 1979). Redflied dari pemahaman bersama dan perilaku yang mapan masyarakat memunculkan konsep yang amat penting dalam kegiatan manajemen seperti konsep tentang budaya kerja, yang dibangun atas dasar pemahaman orang (masyarakat) tentang kerja yang ditampilkan dalam bentuk sikap dan perilaku yang mapan (kokoh). Budaya kerja terdapat pada semua jenis pekerjaan, yang muncul dan berkembang setelah melalui proses dan akan terus berkembang, menjadi pedoman para anggota organisasi dalam mencapai tujuan. Tinjauan teoritis tentang budaya kerja telah mengungkap berbagai 
pengertian budaya kerja, menurut Robin budaya kerja adalah persepsi umum yang dianut oleh anggota organisasi atau suatu sistem dari pengertian bersama yang dimiliki anggotanya (Robbins, 2001).

Semua nilai, asumsi, norma dan aturan yang ada dalam pikiran dan hati nurani itu akan ditampilkan dalam bekerja melaksanakan Tri Dharma Perguruan Tinggi, budaya kerja yang ada dalam diri seorang anggota organisasi/ karyawan akan nampak pada aktivitasnya dalam menerima tugas. Makna budaya yang berkembang dalam suatu kelompok menurut Schein adalah sebagai berikut: There culture of a group can now be defined as a pattern of share basic assumption that was learned by a group as it solved its problems of external adaption and internal integration, tthat has worked well enoughto be considered valid and therefore. To be taught to new members as the correct way to percive, think and feel in relation to tho problems (Scheun, 2004:17).

Dari pendapat ini, budaya yang berkembang dalam suatu kelompok atau organisasi adalah pola dari asumsi dasar yang disepakati bersama, telah dipelajari oleh anggota kelompok untuk memecahkan suatu masalah yang terkait dengan adaptasi ekternal dan integrasi internal. Budaya berkembang karena sebelumnya sudah ada dan dianggap baik dan oleh karena itu dapat diajarkan pada anggota yang baru sebagai cara yang benar untukmenyadari, berpikir, serta merasakan hubungan dalam menghadapi masalahmasalah kelompok.

Selanjutnya dikatakan bahwa, budaya kerja adalah suatu falsafah yang didasari oleh pandangan hidup sebagai nilai-nilai yang menjadi sifat, kebiasan kekuatan pendorong, membudaya dalam kehidupan suatu kelomok, masyarakat atau organisasi yang tercermin dalam perilaku, kepercayaan, cita-cita, pendapat dan tindakan yang terwujud dalam kerja atau bekerja (Triguna, 1997). Dalam konteks pekerjaan, Letzioni menjelaskan pengertian budaya kerja sebagai berikut: Work culture is common sense that a worker brings to work. The work culture consists of the shared attitudes toward work, the share beliefs not about this work place, but work in general, the common expectations about behavior, the ritual of work, the traditional work, the way things have always been done (Letzioni, 2004).

Budaya kerja memberi makna bagaimana anggota organisasi memiliki persepsi terhadap nila-nilai dalam organisasi yang menentukan bagaimana anggotanya bertindak dan berperilaku. Budaya kerja dapat aktif mendorong atau melemahkan tergantung pada arti dari nilai, kepercayaan dan norma-norma, sependapat dengan hal tersebut, Susanto mengemukakan bahwa budaya kerja merupakan nilai-nilai yang menjadi pegangan sumberdaya manusia dalam menjalankan 
kewajiban perilakunya di dalam organisasi (Susanto).

Semua anggota lembaga tempat bekerja seharusnya memenuhi nilai-nilai etis atau etika (ajaran perilaku terpuji), yaitu suatu kumpulan prinsip-prinsip atau pandangan tentang tindakan dan tingkah laku dalam bekerja secara baik/bijak, menghindarkan hal-hal yang tercela. Yang mendasar dari konsep ini menunjukkan bahwa budaya kerja merupakan realisasi niali-nilai yang dimiliki untuk senantiasa bekerja keras, berhasil dan terpuji menjalankan tugas dan fungsi sesuai dengan tujuan dari lembaga atau instansi tempat bekerja. Dari definisi budaya kerja tersebut menunjukkan betapa pentingnya budaya kerja yang harus dimiliki oleh setiap dosen.

Penjelasan lain tentang budaya kerja di kemukakan Applebaum: Work culture are social environtments which make demands upon people. They require behavior which is deemed appropriate for successful role functioning, and they punish those whose behavior is in appropriate. Workenvironments are made up of individuals and social structures. Individuals bring skills, knowledge and abilities to the work environment. The social structure is made up of the physical work plave, the work techniques and the organizational hierarchy established by custom and tradition in the enterprise or occupation (Applebaum, 2004).

Berdasarkan pendapat di atas, budaya kerja merupakan lingkungan sosial yang membuat tuntutan pada setiap orang. Budaya kerja yang berkembang dalam organisasi tempat bekerja akan menjadi kewajiban bagi setiap warganya. Setiap warga organisasi harus dapat memenuhi perilaku yang dianggap tepat untuk kesuksesan fungsi dan perannya, dan mereka akan mendapat hukuman atas perilaku yang tidak pantas.

Hal ini mengisyaratkan bahwa budaya organisasi yang kondusif dapat membangun komitmen bersama para anggota organisasi untuk memperjuangkan pencapaian tujuan organisasi. Hasil penelitian Lok \& Crawford juga memperlihatkan pengaruh budaya organisasi terhadap komitmen organisasi (Crawford, 2004). Berarti bahwa budaya organisasi memiliki pengaruh langsung terhadap komitmen organisasi. Budaya kerja akan menjadi dasar utama dalam pembentukan budaya organisasi.

\section{Integritas}

Pada dasarnya integritas adalah konsistensi dan keteguhan yang tak tergoyahkan dalam menjunjung tinggi nilai-nilai luhur dan keyakinan definisi lain dari integritas adalah suatu konsep yang menunjuk konsistensi antara tindakan dengan nilai dan prinsip. Dalam etika, integritas diartikan sebagai kejujuran dan kebenaran dari tindakan seseorang. Seseorang dikatakan mempunyai integritas apabila tindakannya sesuai dengan nilai, keyakinan, dan prinsip yang 
dipegangnya, ditandai oleh satunya kata dan perbuatan bukan seorang yang kata-katanya tidak dapat dipegang.

Schemerhon mendefinisikan bahwa integritas sebagai kejujuran, kredibilitas dan konsistensi seorang pemimpin dalam menempatkan nilai-nilai kedalam tindakan. Para pemimpin memiliki tanggung jawab yang tidak dapat ditolak untuk menetapkan standar-standar yang tinggi guna membimbing perilaku pengikutnya (Schermerhon, 2000). Integritas dapat diartikan sebagai suatu yang lebih sekedar pengaturan sistem keyakinan, termasuk didalamnya konsistensi antara visi dan tindakan, antara nilai-nilai yang diyakini dengan nilainilai yang dipraktekkan (Srivastiva, 1989).

Kemudian ditegaskan bahwa integritas mencakup: (a) kejujuran; (b) keadilan dan ketulusan yang lebih besar terhadap orang lain. Melengkapi pendapat sebelumnya, integritas dapat juga didefinisikan sebagai menetapkan adil dan berupaya untuk menerapkannya dalam kehidupan sehari-hari standar personal yang tinggi bagi diri sendiri yang mencakup kejujuran, tanggung jawab, menghormati orang lain dan bersikap hati-hati. Jika dirujuk pada definisi tersebut, integritas pada dasarnya merupakan gambaran keselarasan antara (1) hal-hal yang diidam-idamkan seseorang dengan tindakannya; (2) nilai-nilai yang diyakini seseorang dengan yang dipraktekkannya yang muncul dari kesadaran diri dan keyakinannya terhadap orang lain; dan (3) memiliki kejujuran, tanggung jawab dan menghormati orang lain.

Integritas dapat diartikan sebagai suatu yang lebih sekedar pengaturan sistem keyakinan, termasuk di dalamnya konsistensi antara visi dan tindakan, antara nilai-nilai yang diyakini dengan nilainilai yang dipraktekkan. Selanjutnya ditegaskan bahwa upaya mencapai integritas yang optimal dapat dilakukan dengan cara mencari halhal yang ideal, mencari gambaran citra ideal yang aspiratif dan integrasi secara keseluruhan. Pendapat lain menyimpulkan integritas sebagai basis dari kesadaran diri sendiri dan keyakinan yang ditanamkan pada orang lain. Integritas dapat juga berarti sebagai melayani orang-orang dengan tujuan positif, bukan demi kepentingan memberi pelayanan itu sendiri (Merril et.all,1999). Selanjutnya ditegaskan bahwa integritas mencakup: (a) kejujuran; (b) keadilan dan ketulusan yang lebih besar terhadap orang lain. Dari beberapa pengertian tersebut, maka dapat dikatakan bahwa integritas adalah standar personal yang mencakup kejujuran, tanggung jawab, konsisten terhadap nilai-nilai dan tindakan, menghormati orang lain, menerapkan azas keadilan terhadap sesama. Jadi dari beberapa pengertian tersebut, yang dimaksud dengan integritas adalah perilaku seseorang yang konsisten dengan prinsip yang dianut mencakup memiliki kejujuran, 
bersikap adil, konsisten terhadap nilai, memiliki tanggungjawab.

Berdasarkan uraian sebelumnya, dapat disintesiskan bahwa integritas adalah perilaku seseorang yang konsisiten dan keteguhan seseorang menempatkan nili-nilai kebaikan didalam tindakannya dalam menjalankan tugasnya. Yang ditunjukan dengan indikator: memiliki kejujuran, (2) bersikap adil, (3) konsisten terhadap nilai, (4) memiliki tanggung jawab.

\section{Kepercayaan(Trust)}

Definisi kepercayaan dikemukakan oleh beberapa ahli berdasarkan pada sudut pandang masing-masing. Menurut Blau Schurr dan Ozane mendefinisikan kepercayaan sebagai suatu keyakinan bahwa pernyataan pihak lain dapat diandalkan untuk memenuhi kewajibannya (Schur, 1985). Selanjutnya menurut Barnes, kepercayaan adalah keyakinan bahwa seseorang akan menemukan apa yang diinginkan pada mitra pertukaran. Kepercayaan melibatkan kesediaan seseorang untuk bertingkahlaku tertentu karena keyakinan bahwa mitranya akan memberikan apa yang ia harapkan dan suatu harapan yang umumnya dimiliki seseorang bahwa kata, janji atau pernyataan orang lain dapat dipercaya (Barnes, 2003). Sedangkan McShane dan Von Glinow memberikan batasan kepercayaan pada harapan positif dan terjadi dalam dua arah, Trust refers to positive expectations one person has toward another person in situations involving risk, trust means putting faith in the other person or group. It also a reciprocal activity: to recive trust you must demonstrate trust (McShaneVonGlinow, 2008). Pendapat senada dari Colquitt, Lepine and Wesson mendefinisikan kepercayaan sebagai kesediaan untuk menerima otoritas berdasarkan harapan positif tentang tindakan otoritas dan intensinya ...trust is defined as the wllingness tobe vulnerable to an anthority based on positive expectations about the authority's actions and intentions (Colquitt, 2009).

Kepercayaan mengacu pada harapan positif satu orang ke orang lain dalam situasi yang melibatkan resiko, kepercayaan berarti menempatkan keyakinan pada orang lain atau kelompok. Sementara itu menurut Mullins, kepercayaan termasuk dalam salah satu kebutuhan yang seorang pegawai harus dimiliki dalam menimbulkan rasa gembira dalam bekerja, seperti kebutuhan-kebutuhan lainnya yaitu kebanggaan dan akuntabilitas hasil. Semua ini diperlukan agar keragaman termotivasi dalam bekerja (Mullins, 2005). Sejalan dengan pendapat di atas, Robbins menyatakan bahwa kepercayaan merupakan kondisi psikologis seseorang yang muncul ketika dipengaruhi oleh orang lain karena memiliki harapan positif terhadap sesuatu. Rasa saling percaya antara pimpinan dan bawahannya dihubungkan dengan sejumlah hasil yang positif.

Available at.

http://journal.unj.ac.id/unj/index.php/econosains/article/view/939 
Selanjutnya dijelaskan oleh Fred Luthans bahwa membangun kepercayaan sesuai dengan prinsipprinsip dalam pemberian wewenang dalam suatu organisasi dapat mendorong anggota untuk mengembangkan ide-ide dengan cepat, berani mengambil resiko dan melakukan inovasi, sehingga dapat meningkatkan kinerja organisasi. Sejalan dengan pendapat Luthans, dan John M. Ivancevich menjelaskan bahwa kepercayaan merupakan karakteristik yang sangat penting dari anggota suatu kelompok, kepercayaan tersebut harus muncul dalam suatu kelompok untuk membentuk kinerja yang tinggi. Untuk mendorong terbentuknya kepercayaan diantara manajer dan anggotanya, dapat dikembangkan melalui komunikasi yang baik diantara keduanya (Luthans, 2008).

Kreitner Robert menjelaskan bahwa faktor kepercayaan dalam suatu organisasi menjadi sangat penting dalam mendukung kinerja pimpinan. Karena dengan adanya kepercayaan pimpinan terhadap anggota akan menimbulkan rasa tanggung jawab kebersamaan dan rasa memiliki dari seluruh angggotanya. Kepercayaan juga akan memunculkan ide-ide innovtif untuk meningkatkan kualitas organisasi (Kinicki, 2007).

\section{METODE PENELITIAN}

Metode yang dipakai dalam penelitian ini adalah metode survei dengan menggunakan pendekatan kuantitatif dan menjelaskan hubu- ngan kausal dengan analisis jalur (path analysis). Hasil uji coba instrumen organizational citizenship behavior dari 30 butir yang diujicobakan, terdapat 3 butir yang tidak valid dengan koefisien reliabilitas instrumen sebesar 0,936 . Hasil analisis uji coba instrumen budaya kerja diketahui bahwa dari 30 butir yang diujicobakan, terdapat 1 butir yang tidak valid dengan koefisien reliabilitas instrumen sebesar 0,941. Hasil analisis uji coba instrumen integritas diperoleh nilai dari 30 butir yang diujicobakan, terdapat 1 butir yang tidak valid dengan koefisien reliabilitas instrumen sebesar 0,935. Hasil analisis uji coba instrumen kepercayaan diperoleh nilai dari 30 butir yang diujicobakan, terdapat 1 butir yang tidak valid dengan koefisien reliabilitas instrumen sebesar 0,961. Analisis data dilakukan dengan statistika deskriptif dan inferensial.

\section{HASIL PENELITIAN DAN PEMBAHASAN}

Berdasarkan hasil analisis data dan perhitungan statistik, temuan hasil penelitian adalah sebagai berikut: (1). Budaya kerja berpengaruh langsung positif terhadap organizational citizenship behavior dengan koefisien jalur 0,474 (2). integritas berpengaruh langsung positif terhadap organizational citizenship behavior dengan koefisien jalur 0,330 (3). Kepercayaan berpengaruh langsung positif terhadap organizational 
citizenship behavior dengan koefisien jalur 0,248. (4) budaya kerja berpengaruh langsung positif terhadap kepercayaan dengan koefisien jalur 0,295. (5) integritas berpengaruh langsung positif terhadap kepercayaan dengan koefisien jalur 0,414, dan (6) ) budaya kerja berpengaruh langsung positif terhadap integritas dengan koefisien jalur 0,539. Dengan demikian terdapat pengaruh budaya terhadap organizational citizenship behavior. Integritas berpengaruh terhadap organizational citizenship behavior, kepercayaan berpengaruh terhadap organizational citizenship behavior, budaya kerja berpengaruh terhadap kepercayaan, integritas berpengaruh terhadap kepercayaan dan budaya kerja berpengaruh terhadap integritas, sehingga implikasinya adalah upaya peningkatan organizational citizenship behavior dilakukan melalui budaya kerja, integritas dan kepercayaan.

Hasil Analisis Jalur Pengaruh Budaya kerja,Integritas, dan Kepercayaan terhadap OCB

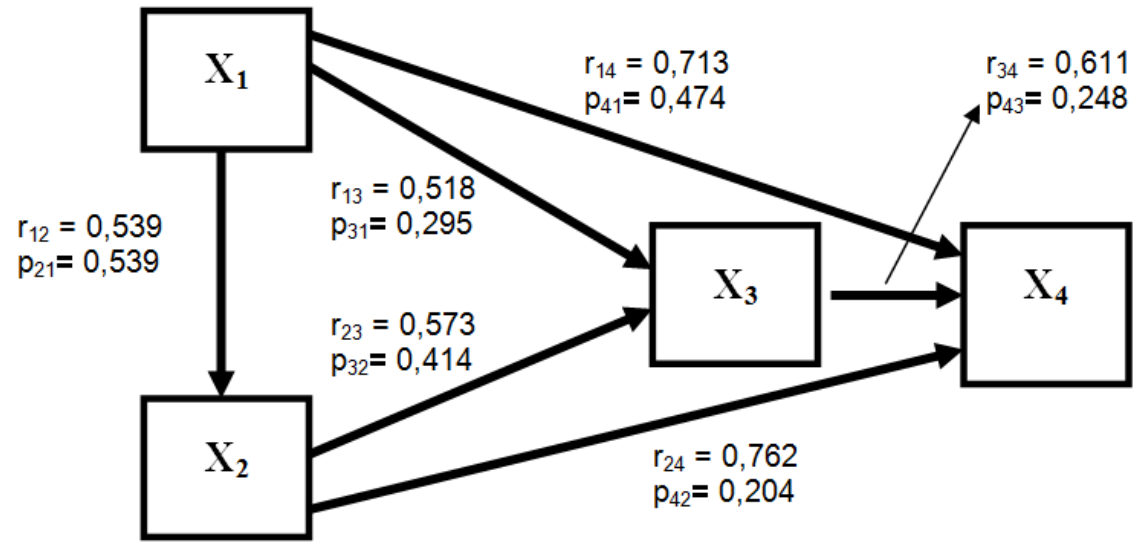

Keterangan:

$\mathrm{X}_{1}=$ budaya kerja

$\mathrm{X}_{2}=$ integritas

$\mathrm{X}_{3}=$ kepercayaan

$\mathrm{X}_{4}=\mathrm{OCB}$

Hasil penelitan ini menunjukkan bahwa budaya kerja memberikan pengaruh langsung positif terhadap OCB. Besarnya pengaruh tersebut ditunjukkan oleh koefisien korelasi 0,713 dan koefisien jalur 0,474 . Hal ini menujukkan bahwa budaya kerja dapat meningkatkan OCB dosen
UNJ, maka keyakinan nilai-nilai dalam perilaku dan tindakannya yang terwujud dalam kerja atau bekerja yang dapat disebut sebagain budaya kerja, maka diduga budaya kerja berpengaruh langsung pada Organiztional Citizenship Behavior (OCB). 
Integritas memberikan pengaruh langsung positifterhadap OCB. Besarnya pengaruh tersebut ditunjukkan oleh koefisien korelasi 0,602 dan koefisien jalur 0,204.

Kepercayaan memberikan pengaruh langsung positif terhadap OCB. Besarnya pengaruh tersebut ditunjukkan oleh koefisien korelasi 0,611 dan koefisien jalur 0,248. Organisasi pada umumnya percaya bahwa untuk membangun keunggulan harus mengusahakan kinerja individual yang semaksimal mungkin, karena pada dasarnya hal ini akan mempengaruhi kinerja tim, sehingga mepengaruhi pula kinerja keseluruhan organisasi. Ketika kepercayaan telah ada pada diri para dosen maka akan dengan suka rela melibatkan diri dalam berbagai aktivitas organisasi, dan tetap bertahan dalam kondisi apapun. Dari uraian tersebut, dapat diduga terdapat pengaruh positif kepercayaan terhadap organizational citizenship behavior.

Hasil penelitan ini menunjukkan bahwa budaya kerja memberikan pengaruh positif secara langsung terhadap kepercayaan. Besarnya pengaruh tersebut ditunjukkan oleh koefisien korelasi 0,518 dan koefisien jalur 0,295. Nilai budaya merupakan suatu prinsip yang mendasari kepercayaan kepada sesuatu yang terdefinisi oleh sesuatu budaya di tempat tinggalnya. Nilai-nilai yang kuat dalam budaya organisasi bisa saja konsisten atau tidak konsisten dapat menjadi perekat budaya yang mempertahankan keberpihakan pada organisasi yang dominan. Hal ini diperkuat dengan pendapat Khaerul Umam yang menyatakan bahwa manfaat dari budaya kerja dalam kegiatan kerja antara lain sebagai berikut:

a. Menjamin hasil kerja dengan kualitas yang lebih baik

b. Membuka seluruh jaringan komunikasi, keterbukaan, kebersamaan, kegotong-royongan, kekeluargaan

c. Menemukan kesalahan dan cepat memperbaiki serta cepat menyesuaikan diri dari perkembangan luar

d. Meningkatkan disiplin dan kepuasan kerja

e. Menciptakan pergaulan yang lebih akrab (Khaerul Umam, 2010)

Integritas memberikan pengaruh positif secara langsung terhadap kepercayaan. Besarnya pengaruh tersebut ditunjukkan oleh koefisien korelasi 0,573 dan koefisien jalur 0,414. Jadi, Integritas adalah perilaku yang dilandasi oleh nilai-nilai yang diyakini dan menjadi pedoman dalam melaksanakan tugas yang ditetapkan. Untuk itu, nilai-nilai yang terkandung merupakan dasar yang utama untuk mencapai tujuan dalam suatu lembaga, dan dasar itu harus dibangun melalui kepercayaan. Budaya kerja memberikan pengaruh positif secara langsung terhadap integritas. Besarnya pengaruh tersebut ditunjukkan oleh koefisien korelasi dan koefisien jalur sebesar 0,539 . Budaya kerja merupakan lingkungan sosial yang membuat 
tuntutan pada setiap orang. Budaya kerja yang berkembang dalam organisasi tempat bekerja akan menjadi kewajiban bagi setiap warganya. Setiap warga organisasi harus dapat memenuhi perilaku yang dianggap tepat untuk kesuksesan fungsi dan perannya, dan mereka akan mendapat hukuman atas perilaku yang tidak pantas. Budaya kerja berkaitan dengan kepatuhan pegawai terhadap peraturan, disiplin dalam menjalankan aturan itu. Sedangkan Integritas adalah perilaku yang dilandasi oleh nilai-nilai yang menjadi pedoman dalam melaksanakan tugas yang ditetapkan.

\section{KESIMPULAN}

Berdasarkan hasil penelitian diperoleh kesimpulan bahwa, Pertama: budaya kerja berpengaruh langsung positif terhadap Organizational Citizenship Behavior (OCB). Artinya, peningkatan budaya kerja mengakibatkan peningkatan OCB dosen Universitas Negeri Jakarta.

Kedua: integritas berpengaruh langsung positif terhadap Organizational Citizenship Behavior (OCB). Artinya, integritas yang tinggi mengakibatkan peningkatan OCB dosen Universitas Negeri Jakarta.

Ketiga: Kepercayaan berpengaruh langsung positif terhadap Organizational Citizenship Behavior (OCB). Artinya, peningkatan kepercayaan mengakibatkan peningkatan OCB dosen Universitas Negeri Jakarta.
Keempat. Budaya kerja berpengaruh langsung positif terhadap kepercayaan. Artinya budaya kerja yang baik akan mengakibatkan tingkat kepercayaan dosen Universitas Negeri Jakarta pun akan meningkat.

Kelima. Integritas berpengaruh langsung positif terhadap kepercayaan. Artinya semakin tinggi integritas seorang dosen akan semakin tinggi pula kepercayaannya terhadap Universitas Negeri Jakarta.

Keenam. Budaya kerja berpengaruh langsung positif terhadap integritas. Artinya budaya kerja yang kondusif akan semakin meningkatkan integritas dosen Universitas Negeri Jakarta.

\section{Saran}

Berdasarkan implikasi penelitian yang dikemukakan di atas dapat diajukan saran-saran praktis untuk perbaikan budaya kerja, integritas, dan peningkatan kepercayaan agar dapat mendorong peningkatan OCB dosen Universitas Negeri Jakarta sebagai berikut:

Pertama, saran untuk pimpinan. Pimpinan diharapkan dapat meningkatkan OCB dengan meningkatkan budaya organisasi yakni: adanya harapan positif, kesempatan bertindak, melakukan komunikasi, membina hubungan sosial, dan adanya anggapan positif. Kedua, saran untuk pimpinan terkait dengan integritas agar dapat meningkatkan OCB. Pimpinan hendaknya memiliki kejujuran, bersikap adil, konsisten terhadap nilai dan memiliki tanggung jawab. 
Ketiga, saran untuk pimpinan terkait dengan kepercayaan agar dapat meningkatkan OCB. Pimpinan hendaknya membangun keyakinan kepada lembaga, saling membantu diantara dosen, ketersediaan mengembangkan ide, dan komunikasi yang efektif.

Keempat, saran untuk penelitian selanjutnya. Belum semua masalah OCB dosen dapat terjawab melalui penelitian ini. Masih banyak faktor yang berpotensi mempengaruhi OCB dosen yang harus dijelaskan melalui penelitian selanjutnya.

\section{DAFTAR PUSTAKA}

A.Baron, G. J. (2000). Behavior in Organizations. New Jersey: PrenticeHall.

Applebaum, H. A. (2004). Work in Market and Industrial Societies.

Barnes, J. 2.-m. (2003). Screats of customer relationship manage-ment. Yogyakarta: Andi.

Colquitt, L. W. (2009). Organizational Behavio. NewYork: McGraw-Hill/Irwin Companies.

Crawford, P. L. (2004). The effect of organisational culture and leadership style on job satisfaction and organisational commitment: A cross-national comparison, Journal of Management
Development. Journal of Management Development.

Judge, R. P. (2008). Perilaku Organisasi Buku. Jakarta : Salemba Empat.

Kinicki, R. K. (2007). Organization Behavior. New York: Mc Graww Hill.

McShane-VonGlinow. (2008). Organi-zational Behavior. New York: McGraw-Hill/Irwin Companies.

Mullins, L. \&. (2005). Organizational Behavior. New York: McGraw-Hill.

Organ. DW.Podsakof, P. \&. (2000). Or-ganizational Citizenship Beha-vior. USA: Sage Publication.

Pettigrew, A. 1.-n. (1979). on Studying Organizational Culture, Admi-nistration Science Quarterly.

Robbins, 2. O.-h.-H. (2001). Organizational Be-havior. New Jersey: Prentice- Hall International.

Schermerhon, J. (2000). Management alih bahasa Arnawa Putranta. Yogyakarta: Andi.

Schur, P. a. (1985). Influences on Exchange Pro-cesses: Buyer's Preconcep-tions of a Seller's Trus-worthiness and Bargaining Toughness. Journal of Consumer Research.

Triguna. (1997). Budaya Kerja. Jakarta: PT Golden Terayon Press. 